\title{
Effect of Cervical Cancer Education and Provider Recommendation for Screening: A Systematic Review
}

\author{
Tetti Solehati ${ }^{1^{*}}$; Bhekti Imansari ${ }^{2}$; Devita Madiu ${ }^{3}$; Cecep Eli Kosasih ${ }^{4}$; Yanti Hermayanti ${ }^{5}$; \\ Henny Suzana Mediani ${ }^{6}$
}

$\left.1^{*}\right), 3,4,5,6$ Faculty of Nursing, Padjadjaran University

\section{ARTICLE INFO \\ Article history: \\ Received October 08, 2020 \\ Accepted November 17, 2020 \\ Published December 05, 2020}

\section{Keyword:}

Cervical cancer

Effect of education

Cancer Screening

\begin{abstract}
A B S T R A C T
The incidence of cervical cancer in the world is still high as well as in Indonesia. This cancer affected women's physically, psychologically, socially, sexually functionally, and spiritually. The purpose of this review literature was to determine the effect of cervical cancer education and to identify the effects of provider recommendations for screening to eligible women, as a basis for developing new interventions for nurses. We used the PICO (Problem or Population, Interventions, Comparison and Outcome) framework to develop our search strategy. Searching for articles was done through four English databases namely CINAHL, Science Direct, Pubmed, and Proquest to identify articles published between 2009-2019. Of the 2,665 filtered research reports, 14 articles were found that met the requirements. The data synthesis and reporting was guided by the Preferred Reporting Items for Systematic Reviews and Meta-analysis (PRISMA). Results, there were eight randomized control trials, five quasi-experiment, and one mix method involved in the analysis step. The interventions were cervical cancer screening methods (1 article), interventions to increase participation in cervical cancer screening (10 articles), postoperative cervical cancer nursing interventions (1 articles), and interventions handling symptoms or problems due to cervical cancer ( 2 articles). Our findings supported the implementation of cervical cancer educational interventions to increase women's participation in cervical cancer screening programs. Nurses and midwifery have the opportunity to innovate interventions related to nursing, through research in order to improve the quality of nursing care for patients.
\end{abstract}

This open access article is under the CC-BY-SA license.
Kata kunci:

Kanker serviks,

Pengaruh pendidikan

Skrining kanker

\section{*) corresponding author}

Faculty of Nursing, Padjadjaran University, Jalan Raya Bandung Sumedang KM 21 Jatinangor, Jawa Barat-Indonesia

Email: tetti.solehati@unpad.ac.id

DOI: https://doi.org/10.30604/jika.v5i2.363

\section{A B S T R A K}

Insiden kanker serviks di Indonesia maupun di dunia masih cukup tinggi. Wanita dengan kanker serviks dapat mengalami perubahan secara fisik, psikologis, social dan fungsi seksual, maupun spiritual. Tujuan literatur review ini untuk mengetahui pengelolaan kanker serviks, sebagai dasar pengembangan intervensi baru oleh perawat pada pasien kanker serviks. Pencarian artikel dilakukan melalui empat database yaitu CINAHL, Science Direct, Pubmed dan Proquest. Pencarian data elektronik dilakukan pada bulan September 2019. Didapatkan 15 artikel yang sesuai dengan tema dan kriteria inklusi. Hasil, satu artikel tentang metode skrining kanker serviks, sepuluh artikel tentang intervensi untuk meningkatkan partisipasi skrining kanker serviks, dua artikel tentang intervensi keperawatan post operasi kanker serviks, dan dua artikel tentang intervensi penanganan gejala atau masalah akibat kanker serviks. Masih sedikit intervensi yang dikembangkan oleh perawat, terkait pengelolaan kanker serviks. Perawat memiliki peluang untuk melakukan inovasi intervensi terkait keperawatan, melalui penelitian agar dapat meningkatkan kualitas asuhan keperawatan dan kepuasan pasien. 
This open access article is under the CC-BY-SA license.

\section{Introduction}

Cervical cancer is a disease that causes morbidity and mortality in women. Although cervical cancer can largely be prevented through screening, it remains one of the leading causes of cancer morbidity and mortality globally (Musa et al., 2017). The incidence of cervical cancer in the world is still quite high, as well as in Indonesia. Based on GLOBOCAN (2018) cervical cancer ranks fourth in cancer incidence and mortality in women in the world (Bruni et al., 2018; Ferlay et al., 2015). Whereas in Indonesia, cervical cancer ranks second after breast cancer which causes death in women (Kemenkes, 2019). The high rates of cervical cancer morbidity and mortality must be a concern for women and health workers.

Cervical cancer is a malignant cancerous cell that grows in the cervix caused by Human Papilloma Virus (HPV). There are 100 types of HPV that can infect humans and 2 of them are often the cause of cervical cancer namely HPV16 and HPV18 (Dunleavey, 2008; Harlianty, R., \& Paramastri, I. 2020). Persistent HPV infection can cause cervical precancerous lesions which if left untreated can develop into cancer 10 to 20 years later (WHO, 2014). Symptoms of cervical cancer appear after the cancer develops. Patients with cervical cancer initially complain of sometimes smelly vaginal discharge, bleeding after sexual intercourse, and irregular bleeding (Smeltzer \& Bare, 2009). Whereas in the early stages the patient does not experience symptoms of cervical cancer so that the patient does not check his health and does not immediately seek treatment.

A woman with cervical cancer will experience various changes, both physical, psychological, social and sexual function, as well as spiritual. Changes experienced physically, such as body shape such as vaginal atrophy, stenosis and abnormal bleeding (Cohen, Jhingran, Oaknin, \& Denny, 2019; Thapa et al., 2018). Psychological changes, where women with cervical cancer will experience psychological distress and threaten changes in marital status (Isaka, Inada, Hiranuma, \& Ichikawa, 2017). In addition, the emergence of bad stigma from the environment related to cervical cancer that can have an impact on social relations (Bae \& Park, 2016; Bjelic-Radisic et al., 2012; Pfaendler, Wenzel, Mechanic, \& Penner, 2015).

To prevent morbidity and mortality, it must be treated with appropriate interventions. Nurses have a role to develop or innovate nursing interventions in order to improve the quality of nursing care in cervical canker patients. The purpose of this review literature was to determine the effect of cervical cancer education and provider recommendations for screening for cervical cancer, as a basis for developing appropriate interventions or nurses in cervical cancer patients.

\section{Method}

Searching for articles was carried out through four databases namely Pubmed, CINAHL, Science Direct, and Proquest. An electronic data search was conducted in September 2019. The keywords used in the search were (cervical cancer) AND (nursing care OR nursing intervention).
A total of 2,665 articles were taken based on year criteria. A total of 8 articles were duplicates. A total of 48 articles met the inclusion criteria, namely articles in the form of interventions (randomized control trials, cluster randomized control trials, Mixed methods, and quasi-experimental designs of relevant interventions to cervical cancer), primary studies, not protocol studies, in English, published from 2009 -2019 , fulltext. Then we read the title of the article and filter the articles in accordance with the theme of the article, namely early detection of cervical cancer. We used the PICO (Problem or Population, Interventions, Comparison and Outcome) framework in developing the focused question of the article selected (Higgins \& Green, 2011). The titles and abstracts of all studies taken from electronic database searches were stored in EndNote X5. After removing the duplicates, the remaining titles / abstracts were filtered, study reports that did not meet the review criteria were excluded, eventually 14 articles were included in the analysis. Figure 1 explained the process of selecting articles. The synthesis of our findings was guided by the PRISMA (Preferred Reporting Items for Systematic Reviews and Metaanalysis)(Moher, Liberati, Tetzlaff, \& Altman, 2009). The risk of bias for each study was assessed using the Cochrane Handbook guidelines (Higgins \& Green, 2011).

\section{Results and Discussion}

Our search yielded 2,665 published articles (705 in Pubmed, 1,033 in Science Direct, 36 in CINAHL, and 891 in Proquest). After variable screening filter, we have 1,638 study. We removed 8 duplicate publications, we had 1630 study reports for screening. After screening study titles / abstracts and inclusion criteria we found 48 potentially relevant studies for full-text review and consideration for inclusion, and 1,582 were eliminated because they did not meet the inclusion criteria for further review of full-text. After completing a full-text review, 14 articles were found to be eligible for inclusion in a randomized controlled trial of 8 articles, quasy experiment 5 articles, and 1 research mix method. The study participants in this article consisted of 559 cervical cancer patients, 451 women of cervical cancer who were infected with HIV and as many as 24,658 women of childbearing age.

Literature search results found, one article about cervical cancer screening methods, ten articles on interventions to increase cervical cancer screening participation, one article on postoperative cervical cancer nursing interventions, and two articles on interventions handling symptoms or problems due to cervical cancer. Table 1 explained each article in this literature review.

Based on the results of the literature search, it found intervention educational methods could improve cervical cancer screening, increase cervical cancer screening participation, and post operative cervical cancer nursing interventions 


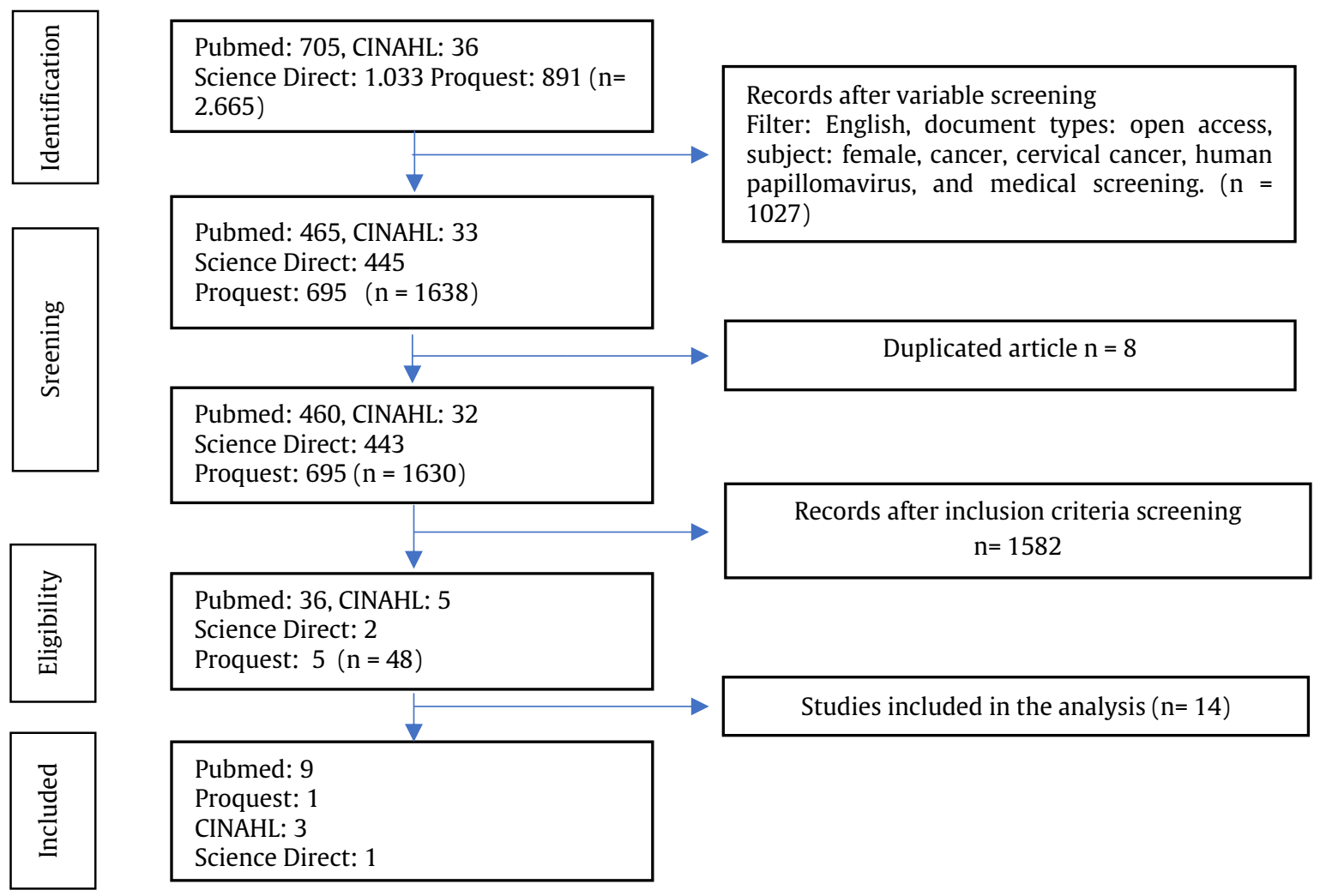

Figure 1: Article selection processes

\section{Cervical Cancer Screening Method}

Based on the literature, cervical cancer screening can be done by the IVA / VILI method, Pap smear and HPV DNA testing. Visual inspection method with acetic acid (IVA) was carried out to determine the development of pre-cancerous lesions before becoming cancerous. In addition, IVA tests have several advantages over other methods, which can be done easily, the results are accurate and fast. For the VILI method, use lugol iodin for cervical examination. The sensitivity level was also good, which is $57 \%-98 \%$, but depends on the quality of staff competence, experience, supervision and quality tools (Cholli et al., 2018).

Another method of screening for cervical cancer is the pap smear, which has become a national screening program in various developed countries, such as Australia. The pap smear method was aimed at women aged 18-70 years. Pap smear tests were carried out regularly, proven effective in reducing mortality from cervical cancer (Kwok \& Lim, 2016).

In addition to IVA / VILI and pap smears, there are cervical cancer screening methods with HPV DNA testing. HPV DNA testing is done by examining genetic material (HPV DNA) on cervical cells. The advantages of HPV DNA testing, namely sampling can be done independently by women with the help of tools, as has been done in various developed countries such as America (Murphy et al., 2016).

\section{Interventions to Increase Cervical Cancer Screening Participation}

Based on the results of a literature search, found various interventions that are used to increase women's participation in cervical cancer screening. The most common intervention is to increase women's knowledge and awareness of cervical cancer screening. The study of Hidago, revealed that strategies to increase screening participation, can be done by providing information about cervical cancer screening, by mail, telephone and coming to group meetings
(Lopez-Torres Hidalgo et al., 2016). In addition, the letter and telephone media can be used as a reminder for cervical cancer screening schedule (Kolutek et al., 2018). Other studies that in line was Han, that the method of health education through brochures, followed by training and counseling by telephone, was effective for increasing cervical cancer screening participation (Han et al., 2017). The study of Ersi, also proved that training and continued by evaluating information obtained through a model based on the health belief model and health promotion model can also increase participation in early detection of cervical cancer compared to just training (Ersin \& Bahar, 2017). Provision of information can not only increase the participation of women who possess that information. However, people around such as their daughters can also increase participation for early detection of cervical cancer (Odunyemi et al., 2018). Various studies to increase knowledge have been carried out proven effective for increasing cervical cancer screening participation. Other studies using leaflets and online were less effective in increasing cervical screening uptake compared to the sampling method itself (Kitchener et al., 2018). There were also studies that use effective cultural and language approach strategies to increase women's knowledge and awareness about breast cancer screening and cervical cancer succeed in increasing the intention and participation in screening mammographs and pap smear tests (Kwok \& Lim, 2016).

In addition to health workers, students can also be involved in strategies to increase participation in cervical cancer screening. This has been proven by research of Weston, where nursing students worked closely with family nursing students to conduct assessments, planning and home visits (Weston et al., 2018). Through this method, the public expresses satisfaction with the services provided and was compelled to screen for cervical cancer. 
Table 1

\section{Interventions in cervical cancer}

\begin{tabular}{|c|c|c|c|c|c|c|c|}
\hline No & $\begin{array}{l}\text { Researcher/ } \\
\text { setting }\end{array}$ & $\begin{array}{c}\text { Research } \\
\text { design }\end{array}$ & Sample & Inclusion criteria & Intervention & Results & Conclusion \\
\hline 1. & $\begin{array}{l}\text { (Lopez-Torres } \\
\text { Hidalgo et al., } \\
\text { 2016) } \\
\text { Lopez-Torres } \\
\text { Hidalgo et al., } \\
2016 . \\
\text { Spanyol }\end{array}$ & $\begin{array}{l}\text { Randomized } \\
\text { controlled trial }\end{array}$ & $\begin{array}{l}1676 \\
\text { women }\end{array}$ & $\begin{array}{l}\text { Women aged 25-70 } \\
\text { years affiliated to the } \\
\text { Albacete Health Area, } \\
\text { located in south-east } \\
\text { Spain, January 2012- } \\
\begin{array}{l}\text { December } 2014 \\
\text { period }\end{array}\end{array}$ & $\begin{array}{l}\text { Group 1: cervical cancer screening information by mail } \\
\text { Group 2: telephone cervical cancer screening information } \\
\text { Group 3: invited to come to group meetings } \\
\text { Group 4: not getting information }\end{array}$ & $\begin{array}{l}\text { Participation in early detection of } \\
\text { cervical cancer within } 2 \text { years in the } \\
\text { information group by mail } 35.3 \% \text {, } \\
\text { telephone } 38.4 \% \text {, face to face } 29.3 \% \text {, and } \\
\text { control group } 26.1 \% \text { Statistically } \\
\text { significant difference between } \\
\text { intervention and control groups (p = } \\
0.005 \text { ). }\end{array}$ & $\begin{array}{l}\text { Interventions in this } \\
\text { study can be a strategy } \\
\text { to increase cervical } \\
\text { cancer adherence and } \\
\text { the most influential is } \\
\text { by telephone. }\end{array}$ \\
\hline 2. & $\begin{array}{l}\text { (Kitchener et } \\
\text { al., 2018) } \\
\text { Kitchener et } \\
\text { al., 2018. } \\
\text { England }\end{array}$ & $\begin{array}{l}\text { Randomized } \\
\text { controlled trial }\end{array}$ & $\begin{array}{l}\text { Phase } 1: \\
20,879 \\
\text { women } \\
\text { Phase } 2: \\
10,126 \\
\text { women }\end{array}$ & $\begin{array}{l}\text { Women in the } \\
\text { Greater Manchester } \\
\text { and Grampian areas, } \\
\text { Scotland }\end{array}$ & $\begin{array}{l}\text { Phase 1: leaflet before invitation or not, and access to } \\
\text { online booking } \\
\text { Phase 2: } \\
\text { - group 1: Vaginal examination kits themselves are sent } \\
\text { without request } \\
\text { - group 2: Self-examination of the vagina is offered } \\
\text { group 3: Vaginal examination kits are provided with } \\
\text { time agreements } \\
\text { - group 4: Access offers by nurse navigators } \\
\text { - group 5: Offers a choice between vaginal examinations } \\
\text { alone or by the navigator nurse } \\
\text { - Control group }\end{array}$ & $\begin{array}{l}\text { - Pre-invitation leaflets and online } \\
\text { ordering were not effective when } \\
\text { compared to the control group } \\
\text { within } 3 \text { months ( } 18.8 \% \text { vs } 19.2 \%) \\
\text { - Absorption of screening at } 3 \text { months } \\
\text { was higher among the group of } \\
\text { women who had been previously } \\
\text { vaccinated with HPV ( } 23.7 \% \text { vs } 11 \%) \text {. } \\
\text { - Among groups who did not meet, } \\
\text { the interventions for sending } \\
\text { independent HPV examinations } \\
\text { showed a statistically significant } \\
\text { increase in the } 12 \text { months after the } \\
\text { same invitation compared to the } \\
\text { group scheduled to meet ( } 21.3 \% \text { vs } \\
16.2 \%)\end{array}$ & $\begin{array}{l}\text { The invitation method } \\
\text { has little effect on } \\
\text { women and it is better } \\
\text { to use the sampling } \\
\text { method alone. }\end{array}$ \\
\hline 3. & $\begin{array}{l}\text { (Cholli et al., } \\
\text { 2018) } \\
\text { Cholli et al., } \\
\text { 2018. } \\
\text { Cameroon }\end{array}$ & $\begin{array}{l}\text { Randomized } \\
\text { controlled trial }\end{array}$ & $\begin{array}{l}913 \\
\text { women: } \\
384 \text { HIV } \\
\text { positive \& } \\
529 \text { HIV } \\
\text { negative }\end{array}$ & $\begin{array}{l}\text { women aged } \geq 30 \\
\text { years, not pregnant } \\
\text { and have no history } \\
\text { of early detection of } \\
\text { cervical cancer by } \\
\text { CBCHS }\end{array}$ & $\begin{array}{l}\text { Visual inspection with Lugol's acetic acid and iodine was } \\
\text { enhanced by digital cervicography (VIA / VIII-DC) with } \\
\text { careHPV, a high-risk human papillomavirus (HR-HPV) } \\
\text { nucleic acid test (HR-HPV) adjusted for low resources; }\end{array}$ & $\begin{array}{l}\text { - Positive results of VIA / VII-DC } 2 \\
\text { times more in HIV-positive than } \\
\text { HIV-negative }(\mathrm{p}<0.0001) \text {. } \\
\text { - HIV positive } 2 \text { times more in HR- } \\
\text { HPV-Positive than HR-HPV negative } \\
(\mathrm{p}<0.0001)\end{array}$ & $\begin{array}{l}\text { HPV care co-testing } \\
\text { with VIA / VILI-DC can } \\
\text { be used and is useful } \\
\text { for detecting false } \\
\text { positive results, but } \\
\text { HPV care requires a } \\
\text { long time from } \\
\text { screening to results for } \\
\text { treatment in one day. }\end{array}$ \\
\hline 4. & $\begin{array}{l}(\text { Han et al., } \\
\frac{2017)}{\text { Han et al., }} \\
2017 \text {. } \\
\text { Washington } \\
\text { DC }\end{array}$ & $\begin{array}{l}\text { Randomized } \\
\text { controlled trial }\end{array}$ & \begin{tabular}{|l|}
560 \\
women
\end{tabular} & $\begin{array}{l}\text { Korean-American } \\
\text { women, aged } 21-65 \\
\text { years, have never } \\
\text { taken a mammogram } \\
\text { (for women aged } \geq 40 \\
\text { years) or pap smears } \\
\text { in the past } 24 \\
\text { months, can read and } \\
\text { write in Korean and } \\
\text { English. }\end{array}$ & $\begin{array}{l}\text { Intervention group: received individually designed cancer } \\
\text { screening brochures followed by CHW-led health literacy } \\
\text { training and monthly telephone counseling with } \\
\text { navigation. } \\
\text { Control group: received publicly available educational } \\
\text { brochures related to breast and uterine cancer. }\end{array}$ & $\begin{array}{l}\text { The Pap smear test was } 13.3 \text { times }(95 \% \\
\mathrm{CI}=7.9,22.3) \text { higher in the intervention } \\
\text { group than in the control group. } \\
\text { The effects of the intervention also } \\
\text { include increased health literacy and } \\
\text { perceptions about cancer screening. }\end{array}$ & $\begin{array}{l}\text { Health literacy, which } \\
\text { focuses on community } \\
\text { health worker (CHW) } \\
\text { interventions, is } \\
\text { successful in } \\
\text { promoting knowledge, } \\
\text { attitudes and behaviors } \\
\text { of cancer screening in } \\
\text { Korean-American } \\
\text { women. }\end{array}$ \\
\hline
\end{tabular}


Jurnal Aisyah: Jurnal Ilmu Kesehatan, 5(2), December 2020, - 185 Tetti Solehati; Bhekti Imansari; Devita Madiu; Cecep Eli Kosasih; Yanti Hermayanti; Henny Suzana Median

\begin{tabular}{|c|c|c|c|c|c|c|c|}
\hline No & $\begin{array}{l}\text { Researcher/ } \\
\text { setting }\end{array}$ & $\begin{array}{l}\text { Research } \\
\text { design }\end{array}$ & Sample & Inclusion criteria & Intervention & Results & Conclusion \\
\hline 5. & $\begin{array}{l}\text { (Kolutek, } \\
\text { Avci, \& Sevig, } \\
\text { 2018) } \\
\text { Kolutek, Avci, } \\
\text { \& Sevig, 2018. } \\
\text { Turkey }\end{array}$ & $\begin{array}{l}\text { Quasi- } \\
\text { experimental } \\
\text { study }\end{array}$ & \begin{tabular}{|l}
153 \\
women
\end{tabular} & $\begin{array}{l}\text { W women aged } \geq 40 \\
\text { years, literate, } \\
\text { married or living } \\
\text { with a partner, not } \\
\text { pregnant or } \\
\text { breastfeeding, did } \\
\text { not participate in the } \\
\text { pilot study of this } \\
\text { study, had no history } \\
\text { of breast or cervical } \\
\text { cancer. }\end{array}$ & $\begin{array}{l}\text { 1. Follow-up at home: done in the second month after } \\
\text { being willing to become a participant. Including } \\
\text { communication with participants, making plans to hold } \\
\text { home visits, and screening breast and cervical cancer } \\
\text { 2. Training: in the third month with lectures, } \\
\text { demonstrations, and question and answer techniques } \\
\text { 3. Reminder telephone interventions: at months } 4 \text { \& } 5 \text {. } \\
\text { counseling and reminder sessions }\end{array}$ & $\begin{array}{l}\text { The frequency of breast self- } \\
\text { examination (BSE) at the last visit } \\
\text { increased to } 84.3 \% \text { compared to pre- } \\
\text { training. } \\
\text { The level of Pap smear practice } \\
\text { significantly increased after the follow- } \\
\text { up visit }\end{array}$ & $\begin{array}{l}\text { Planning effective } \\
\text { follow-up visits to } \\
\text { increase screening } \\
\text { beliefs and behavior in } \\
\text { women. }\end{array}$ \\
\hline 6. & $\begin{array}{l}\text { (Weston, } \\
\text { Page, Jones- } \\
\text { Schubart, \& } \\
\text { Akinlotan, } \\
\text { 2018) } \\
\text { Weston, Page, } \\
\text { Jones- } \\
\text { Schubart, \& } \\
\text { Akinlotan, } \\
\text { 2018. } \\
\text { Texas }\end{array}$ & Mix methode & \begin{tabular}{|l|}
83 \\
women
\end{tabular} & & $\begin{array}{l}\text { Kcollaboration of health workers with nursing students } \\
\text { and family nursing students. Nursing students provide } \\
\text { services from the waiting room and measure TTV, BMI, } \\
\text { and test urine. Next the nursing students report to the } \\
\text { family nursing students and they process together to } \\
\text { make a home visit. } \\
\text { After the examination the student team discussed the } \\
\text { treatment plan with the faculty. Nursing students send } \\
\text { patients home and provide appropriate education while } \\
\text { family nursing students document home visits }\end{array}$ & $\begin{array}{l}\text { From 2015-2016, } 83 \text { women had good } \\
\text { results, including } 75 \text { who screened for } \\
\text { cervical cancer and } 47 \text { were referred for } \\
\text { mammography. Qualitative surveys } \\
\text { reveal that } 95 \% \text { are satisfied and } 100 \% \\
\text { say they will recommend to friends and } \\
\text { family. }\end{array}$ & $\begin{array}{l}\text { innovative } \\
\text { collaboration (health } \\
\text { workers with nursing } \\
\text { students and family } \\
\text { nurse students) } \\
\text { increases access to } \\
\text { cancer screening for } \\
\text { low-income women } \\
\text { while providing } \\
\text { training for FNP } \\
\text { students. }\end{array}$ \\
\hline 7. & $\begin{array}{l}\text { (Li, Huang, } \\
\text { Zhang, \& Li, } \\
\text { 2016) } \\
\text { Li, Huang, } \\
\text { Zhang, \& Li, } \\
\text { 2016. } \\
\text { China }\end{array}$ & $\begin{array}{l}\text { Randomized } \\
\text { controlled trial }\end{array}$ & $\begin{array}{l}226 \\
\text { cervical } \\
\text { cancer } \\
\text { patients }\end{array}$ & 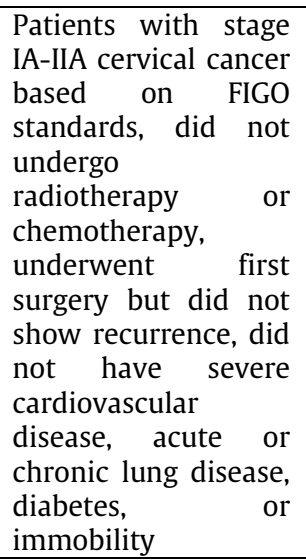 & $\begin{array}{l}\text { The conventional nursing intervention package consists } \\
\text { of: education about medicine, nutrition, health } \\
\text { education about cervical cancer and further education } \\
\text { by telephone. } \\
\text { - The NLHP-HB intervention package consists of: forming } \\
\text { a family care team, physiological rehabilitation, } \\
\text { emotional release management, an informal support } \\
\text { system, monitoring follow-up at home. } \\
\text { - The intervention was carried out for } 6 \text { months. } \\
\text { Participants took the pre-test } 7 \text { days after surgery, and } \\
\text { the post-test was done } 6 \text { months after the intervention. }\end{array}$ & $\begin{array}{l}\text { There was a significant improvement in } \\
\text { the quality of life of patients, after the } \\
\text { intervention }(p=0,000) \text {. }\end{array}$ & $\begin{array}{l}\text { The home-based, } \\
\text { nurse-led health } \\
\text { promotion program } \\
\text { improves the quality of } \\
\text { life, sexual function } \\
\text { and family function in } \\
\text { post-operative patients } \\
\text { with early stage } \\
\text { cervical cancer }\end{array}$ \\
\hline 8. & $\begin{array}{l}\text { Murphy, } \\
\text { Mark, } \\
\text { Anderson, } \\
\text { Farley, } \\
\text { Allen, 2016) } \\
\text { Murphy, } \\
\text { Mark, } \\
\text { Anderson, } \\
\text { Farley, \& }\end{array}$ & $\begin{array}{l}\text { Randomized } \\
\text { controlled trial }\end{array}$ & \begin{tabular}{|l}
94 \\
women
\end{tabular} & $\begin{array}{l}\geq 18 \text { years old, } \\
\text { infected with HIV, } \\
\text { first visit to an HIV } \\
\text { clinic, last screened } \\
\text { for cervical cancer } 18 \\
\text { months ago }\end{array}$ & $\begin{array}{l}\text { - Participants in the intervention group were given the } \\
\text { Hybrid Capture II high-risk HPV DNA test package } \\
\text { (Qiagen. 2003. Gaithersburg, MD, USA.) At the first visit } \\
\text { and provided an explanation of how to use it. In } \\
\text { accordance with the protocol for biohazard safety and } \\
\text { labeling specimens, participants are recommended to } \\
\text { the nearest bathroom to conduct self sampling and } \\
\text { return it to the researcher in the specimen bag. } \\
\text { Furthermore counseling is completed by telephone }\end{array}$ & $\begin{array}{l}\text { The results showed that there was no } \\
\text { significant difference in the completion } \\
\text { of the cytology test within six months } \\
\text { from the baseline between the control } \\
\text { group and the intervention group ( } \mathrm{p}= \\
0.59 \text { ). } \\
\text { However, in the intervention group, } \\
\text { positive HPV testing increased the } \\
\text { threat of cervical cancer significantly in }\end{array}$ & $\begin{array}{l}\text { Self sampling for HPV } \\
\text { testing is feasible, } \\
\text { because it can increase } \\
\text { the threat of cervical } \\
\text { cancer. }\end{array}$ \\
\hline
\end{tabular}


Jurnal Aisyah: Jurnal Ilmu Kesehatan, 5(2), December 2020, - 186

Tetti Solehati; Bhekti Imansari; Devita Madiu; Cecep Eli Kosasih; Yanti Hermayanti; Henny Suzana Median

\begin{tabular}{|c|c|c|c|c|c|c|c|}
\hline No & $\begin{array}{c}\text { Researcher/ } \\
\text { setting }\end{array}$ & $\begin{array}{c}\text { Research } \\
\text { design }\end{array}$ & Sample & Inclusion criteria & Intervention & Results & Conclusion \\
\hline & $\begin{array}{l}\text { Allen, } 2016 . \\
\text { Amerika }\end{array}$ & & & & $\begin{array}{l}\text { about } 2 \text { weeks after the first visit. } 3-5 \text { weeks after the } \\
\text { first visit, participants were interviewed to complete } \\
\text { the modified HBM instrument. } \\
\text { - Participants in the control group were only given a } \\
\text { reminder at the first visit to do the screening. Two } \\
\text { weeks later, a reminder call was made to control and } \\
\text { the last call was made } 3-5 \text { weeks after the first visit, to } \\
\text { complete the modified HBM instrument. } \\
\text { - The main outcome was the completion of a cervical } \\
\text { cytology test within } 6 \text { months of the baseline. The } \\
\text { secondary outcome is the perceived threat of women } \\
\text { developing cervical cancer. }\end{array}$ & $\begin{array}{l}\text { the completion of the cytology test } \\
\text { within six months of the baseline } \\
\text { between the control group and the } \\
\text { intervention group }(\mathrm{p}=0.59) \text {. } \\
\text { However, in the intervention group, } \\
\text { positive HPV testing increased the } \\
\text { threat of cervical cancer. }\end{array}$ & \\
\hline 9. & $\begin{array}{l}\text { (Sharma et al., } \\
\text { 2018) } \\
\text { Sharma et al., } \\
2018 . \\
\text { India }\end{array}$ & $\begin{array}{l}\text { Experimental } \\
\text { study }\end{array}$ & \begin{tabular}{|l|}
207 \\
women
\end{tabular} & $\begin{array}{l}\text { Married women, } \\
\text { aged } \geq 30 \text { years, want } \\
\text { to be screened, not } \\
\text { pregnant and have } \\
\text { no history of cancer / } \\
\text { pre-cancer or have } \\
\text { undergone } \\
\text { hysterectomy a }\end{array}$ & $\begin{array}{l}\text { The IVA "training of trainers" (ToT) program is conducted } \\
\text { for } 3 \text { days for nurses. The participants did an IVA test } \\
\text { illustration during the training. Mobilization activities will } \\
\text { then be carried out, by providing health education to } \\
\text { several maternal and child health centers about the } \\
\text { burden of cervical cancer, risk factors, early signs and the } \\
\text { importance of screening. } \\
\text { The next activity was carried out in the clinic, cervical } \\
\text { images were taken } 1 \text { minute before and after the } \\
\text { application of Acetic Acid 5\%. Pictures are taken using a } \\
\text { smartphone with a } 16 \text { megapixel camera and built-in } \\
\text { flash. The total procedure is around } 15 \text { minutes per } \\
\text { patient. The compiled IVA images must be shown to the } \\
\text { gynecologist every two weeks at the health institute. }\end{array}$ & $\begin{array}{l}\text { Nurses report that there were } 25 \\
(13.8 \%) \text { IVA-positive cases, but only } 19 \\
\text { accessed the referral service. Image } \\
\text { capture and quality have an effect on } \\
\text { expert evaluation. The results also } \\
\text { showed that awareness was still low for } \\
\text { screening and access to referral services }\end{array}$ & $\begin{array}{l}\text { Well-trained nurses } \\
\text { can screen reliably. } \\
\text { Screening and } \\
\text { treatment activities can } \\
\text { reduce drop-out, so } \\
\text { that administrative } \\
\text { administration is } \\
\text { required. }\end{array}$ \\
\hline 10. & $\begin{array}{l}\text { (Kwok \& Lim, } \\
\text { 2016) } \\
\text { Kwok \& Lim, } \\
2016 . \\
\text { China }\end{array}$ & $\begin{array}{l}\text { Quasi- } \\
\text { experimental } \\
\text { dengan desain } \\
\text { pre dan post- } \\
\text { test }\end{array}$ & $\begin{array}{l}288 \\
\text { women }\end{array}$ & $\begin{array}{l}\text { Chinese-Australian } \\
\text { women aged } \geq 18 \\
\text { years, have no } \\
\text { history of cervical } \\
\text { cancer or breast } \\
\text { cancer, can speak } \\
\text { Cantonese, are able } \\
\text { to read and write in } \\
\text { Chinese }\end{array}$ & $\begin{array}{l}\text { The "Happy and healthy life in Sydney" program is a } \\
\text { culture and language sensitive breast and cervical cancer } \\
\text { education program, which focuses on the promotion of } \\
\text { knowledge. The education program is delivered in the } \\
\text { form of PowerPoints lasting } 35 \text { to } 40 \text { minutes in the spaces } \\
\text { provided. } \\
\text { At the end of the program, participants were given an } \\
\text { information package to take home, in the form of an } \\
\text { information booklet using simple language and pictures, a } \\
\text { calendar containing reminders about the date of } \\
\text { mammography and Pap smear tests, contacts for booking } \\
\text { appointments, and souvenirs. }\end{array}$ & $\begin{array}{l}\text { The results showed increased intention } \\
\text { and participation in screening } \\
\text { mammographs and pap smear tests } \\
\text { over a } 6 \text {-month period (all } \mathrm{p}<0.05 \text { ). }\end{array}$ & $\begin{array}{l}\text { The "Happy and } \\
\text { healthy life in Sydney" } \\
\text { program uses effective } \\
\text { cultural and language } \\
\text { approach strategies to } \\
\text { increase women's } \\
\text { knowledge and } \\
\text { awareness about breast } \\
\text { and cervical cancer } \\
\text { screening. }\end{array}$ \\
\hline 11 & $\begin{array}{l}\text { (Afiyanti, } \\
\text { Rachmawati, } \\
\text { \& Milanti, } \\
\text { 2016) } \\
\text { Afiyanti, } \\
\text { Rachmawati, } \\
\text { \& Milanti, } \\
2016 \text { Indone.sia }\end{array}$ & $\begin{array}{l}\text { Quasi- } \\
\text { experimental } \\
\text { dengan desain } \\
\text { one group pre } \\
\text { dan post-test }\end{array}$ & $\begin{array}{l}53 \\
\text { servical } \\
\text { cancer } \\
\text { patients } \\
\text { and } \\
\text { couples }\end{array}$ & $\begin{array}{l}\text { Patients with cervical } \\
\text { cancer with stage } 2 \\
\text { or } 3 \text { who complete } \\
\text { chemotherapy for } 1 \\
\text { year. }\end{array}$ & $\begin{array}{l}\text { Nursing care intervention packages on sexuality, } \\
\text { consisting of } 3 \text { sessions, namely: information on cervical } \\
\text { cancer, solving of sexual problems, practices and exercise. } \\
\text { The nursing intervention was carried out for } 6 \text { weeks, } \\
\text { which was divided into } 2 \text { sessions. }\end{array}$ & $\begin{array}{l}\text { Nursing care intervention packages on } \\
\text { sexuality can reduce symptoms of } \\
\text { dyspareunia }(p=0,000) \text {, increase } \\
\text { vaginal lubrication }(p=0,000) \text {, increase } \\
\text { sexual satisfaction }(0,000) \text { increase } \\
\text { sexual arousal }(p=0.002) \text {, sexual desire } \\
(p=0.012) \text { and orgasm between } \\
\text { cervical cancer patients and their } \\
\text { partners }(p=0.002)\end{array}$ & $\begin{array}{l}\text { Nursing care } \\
\text { intervention packages } \\
\text { on sexuality can be } \\
\text { used as supportive care } \\
\text { and important aspects } \\
\text { in the nursing } \\
\text { standards of cancer } \\
\text { patients in Indonesia. }\end{array}$ \\
\hline
\end{tabular}


Jurnal Aisyah: Jurnal Ilmu Kesehatan, 5(2), December 2020, - 187

Tetti Solehati; Bhekti Imansari; Devita Madiu; Cecep Eli Kosasih; Yanti Hermayanti; Henny Suzana Median

\begin{tabular}{|c|c|c|c|c|c|c|c|}
\hline No & $\begin{array}{l}\text { Researcher/ } \\
\text { setting }\end{array}$ & $\begin{array}{l}\text { Research } \\
\text { design }\end{array}$ & Sample & Inclusion criteria & Intervention & Results & Conclusion \\
\hline 12 & $\begin{array}{l}\text { (Zhang, Li, Li, } \\
\text { \& Chen, 2019) } \\
\text { Zhang, Li, Li, \& } \\
\text { Chen, 2019. } \\
\text { China }\end{array}$ & $\begin{array}{l}\text { Randomized } \\
\text { controlled trial }\end{array}$ & $\begin{array}{l}70 \\
\text { cervical } \\
\text { cancer } \\
\text { patients }\end{array}$ & $\begin{array}{l}\text { Women who were } \\
\text { diagnosed with } \\
\text { cervical cancer, had } \\
\text { completed radiation } \\
\text { and chemotherapy } \\
<1 \text { month, patients } \\
\text { who met diagnostic } \\
\text { criteria for insomnia } \\
\text { according to the } \\
\text { research objectives. }\end{array}$ & $\begin{array}{l}\text { Subjective sleep parameters (CNS) include sleep diary and } \\
\text { insomnia severity index (ISI), while objective sleep } \\
\text { parameters (OSP) including polysomnography (PSG) and } \\
\text { wrist actigraphy are used as baseline data for the } \\
\text { intervention group (MBSR) or control group. PSG data are } \\
\text { an average of night } 2 \text { and night } 3 \text { for each assessment } \\
\text { point. }\end{array}$ & $\begin{array}{l}\text { The results showed that the reduction } \\
\text { of stress in terms of mindfulness had a } \\
\text { positive effect on subjective sleep } \\
\text { parameters }(p<0.01) \text {. There is no } \\
\text { relationship between subjective sleep } \\
\text { parameters and objective sleep } \\
\text { parameters }\end{array}$ & $\begin{array}{l}\text { Mindfulness-based } \\
\text { stress reduction has a } \\
\text { definite impact on } \\
\text { patients with insomnia } \\
\text { that is secondary to } \\
\text { cervical cancer after } \\
\text { the intervention, but } \\
\text { there is no long-term } \\
\text { effect. }\end{array}$ \\
\hline 13 & $\begin{array}{l}\text { (Ersin \& } \\
\text { Bahar, 2017) } \\
\text { Ersin \& Bahar, } \\
\text { 2017. } \\
\text { Turki }\end{array}$ & $\begin{array}{l}\text { Quasi- } \\
\text { experimental } \\
\text { study }\end{array}$ & $\begin{array}{l}100 \\
\text { women }\end{array}$ & $\begin{array}{l}\text { Women> } 40 \text { years } \\
\text { old, have no breast } \\
\text { lumps, have never } \\
\text { been diagnosed with } \\
\text { breast cancer or } \\
\text { cervical cancer, have } \\
\text { not performed breast } \\
\text { self-examination or } \\
\text { have never had a pap } \\
\text { test, mammography } \\
\text { and CBE and have } \\
\text { never had a } \\
\text { hysterectomy. }\end{array}$ & $\begin{array}{l}\text { Intervention Group: Training with an average duration of } \\
65 \text { minutes and is conducted per individual in the } \\
\text { participant's home. After the training, participants were } \\
\text { asked to show what they had learned in a rough little } \\
\text { model and distributed brochures (about breast cancer and } \\
\text { cervical cancer) } \\
\text { Control group: after the training, the group does not apply } \\
\text { anything and brochures are distributed }\end{array}$ & $\begin{array}{l}\text { The comparison of the intervention } \\
\text { group and the control group in BSE } \\
\text { behavior, } C B E \text { and mammography was } \\
\text { significant }(p<0.05) \text {. }\end{array}$ & $\begin{array}{l}\text { Nursing interventions } \\
\text { based on the Health } \\
\text { Belief Model and the } \\
\text { Health Promotion } \\
\text { Model produce positive } \\
\text { changes in the early } \\
\text { detection of cervical } \\
\text { and breast cancer. }\end{array}$ \\
\hline 14 & $\begin{array}{l}\text { (Odunyemi, } \\
\text { Ndikom, \& } \\
\text { Oluwatosin, } \\
\text { 2018) } \\
\text { Odunyemi, } \\
\text { Ndikom, \& } \\
\text { Oluwatosin, } \\
\text { 2018. } \\
\text { Nigeria }\end{array}$ & $\begin{array}{l}\text { Quasi-experim } \\
\text { ental study }\end{array}$ & \begin{tabular}{|l|l|}
146 \\
women
\end{tabular} & $\begin{array}{l}\text { Age> } 18 \text { years, } \\
\text { mothers with } \\
\text { daughters, have no } \\
\text { history of cervical } \\
\text { cancer, and are } \\
\text { willing to participate } \\
\text { in research. }\end{array}$ & $\begin{array}{l}\text { Intervention Group: 2-day workshop on cervical cancer } \\
\text { and HPV vaccine } \\
\text { Control group: not treated }\end{array}$ & $\begin{array}{l}\text { Intervensi memengaruhi penerimaan } \\
\text { vaksinasi } \mathrm{HPV}(\mathrm{P}<0,0001)\end{array}$ & $\begin{array}{l}\text { Nursing interventions } \\
\text { have been shown to } \\
\text { increase maternal } \\
\text { knowledge about } \\
\text { cervical cancer and the } \\
\text { reception of HPV } \\
\text { vaccinations. }\end{array}$ \\
\hline
\end{tabular}


Jurnal Aisyah: Jurnal Ilmu Kesehatan, 5(2), December 2020, - 188

Tetti Solehati; Bhekti Imansari; Devita Madiu; Cecep Eli Kosasih; Yanti Hermayanti; Henny Suzana Mediani

Another intervention to improve cervical cancer screening was done by self-sampling HPV DNA. The study of Murphy, tested the effectiveness of HPV self-sampling to promote cervical cancer screening, compared to standard services via reminders and telephone reminders (Murphy et al., 2016). The results showed that there was no significant difference in the completion of the cytology test within six months from the baseline between the control group and the intervention group $(p=0.59)$. Although there were no significant differences, the results of the study indicate that self-sampling for HPV testing was feasible. While the research of Kitchener, revealed different results, that the self-sampling method showed a significant increase in cervical cancer screening participation (Kitchener et al., 2018). It can be concluded, that self-sampling was feasible as a strategy to improve cervical cancer screening.

Based on the results of the literature, also found intervention using a smartphone. The research of Sharma, tested the feasibility of a cervical cancer screening program using smartphone images, taken by nurses (Sharma et al., 2018). Previously, the IVA "training of trainers" (ToT) program was conducted for 3 days for nurses, and nurses also did IVA test illustrations during the training. The IVA pictures taken by the nurse will later be shown to the gynecologist every two weeks at the prepared health institute. From nurses' reports, 25 (13.8\%) IVA cases were found positive, but only 19 accessed the referral service. This showed that women's awareness was still low for screening and access to referral services. In addition, image capture and image quality taken have an effect on the evaluation of gynecologists. Thus, high-quality smartphone devices were needed in this intervention. This shows that there were still weaknesses of this smartphone image intervention.

\section{Intervention Handling of Symptoms in Cervical Cancer Patients}

The results of our literature review found two interventions used to treat symptoms or problems that arise from cervical cancer. The research of Afiyanti, evaluated the effectiveness of nursing care intervention packages on sexuality, which consisted of 3 sessions, namely: information on cervical cancer, solving of sexual problems, practices and exercise. The nursing intervention was carried out for 6 weeks, which was divided into 2 sessions (Afiyanti et al., 2016). The results showed that the package of nursing care interventions on sexuality can reduce symptoms of dyspareunia $(\mathrm{p}=0,000)$, increase vaginal lubrication $(\mathrm{p}=$ $0,000)$, increase sexual satisfaction $(0,000)$ increase sexual arousal $(\mathrm{p}=0.002)$, sexual desire $(\mathrm{p}=0.012)$ and orgasm among cervical cancer patients and their partners ( $\mathrm{p}=$ 0.002 ). Thus, the nursing care intervention package on sexuality can be used as supportive care and an important aspect in the nursing standards of cancer patients in Indonesia.

Another research conducted by Zhang, which showed that mindfulness-based stress reduction had a positive effect on subjective sleep parameters ( $p<0.01$ ) (Zhang et al., 2019). Subjective sleep parameters (CNS) were used, including sleep diary and insomnia severity index (ISI), while objective sleep parameters (OSP) including polysomnography (PSG) and wrist actigraphy are used as baseline data for the intervention group (MBSR) or control group. It was concluded that mindfulness-based stress reduction has a definite impact on patients with insomnia that was secondary to cervical cancer after the intervention, but there is no long-term effect.

\section{Nursing Interventions Post Cervical Cancer Surgery}

Based on the results of the literature review, there is a postoperative nursing intervention. Post-operative intervention was demonstrated by research $\mathrm{Li}$, that the home-based program, nurse-led health promotion (NLHP$\mathrm{HB}$ ) improves the quality of life, sexual function and family function in post-operative patients with early-stage cervical cancer (Li et al., 2016). The NLHP-HB intervention package consists of: forming a family care team, physiological rehabilitation, emotional release management, an informal support system, monitoring follow-up at home. It can be concluded that, nurses can implement these interventions, to improve the quality of care for post-operative patients with cervical cancer.

\section{Conclusions and Recommendations}

Cervical cancer education and providers have proven effective in dealing with problems related to cervical cancer. Nurses can develop new interventions for nurses. Nurses have a role in the management of cervical cancer. However, there are still few interventions developed by nurses. Nurses can play a role in strategies to increase cervical cancer screening participation, such as providing education through various media, remembering screening and counseling schedules and home visits. In addition, it can also be done through HPV self-sampling. For the post-operative stage of cervical cancer, nurses can use evidence-based practice, such as home-based, nurse-led health promotion (NLHP-HB). For handling symptoms or problems caused by cervical cancer, can be done with a package of nursing interventions on mindfulness and stress reduction with mindfulness.

The article is useful for improving the Nurses to develop interventions the management of cervical cancer. This review is beneficial for health provider as an evidence base in order to increase knowledge and healthy behavior of women.

\section{Declaration of Conflicting Interests}

The authors declared that no potential conflicts of interests with respect to the authorship and publication of this article.

\section{References}

Afiyanti, Y., Rachmawati, I. N., \& Milanti, A. (2016). Evaluating sexual nursing care intervention for reducing sexual dysfunction in Indonesian cervical cancer survivors. AsiaPacific journal of oncology nursing, 3(3), 266.

Bae, H., \& Park, H. (2016). Sexual function, depression, and quality of life in patients with cervical cancer. Supportive care in cancer, 24(3), 1277-1283.

Bjelic-Radisic, V., Jensen, P. T., Vlasic, K. K., Waldenstrom, A.-C., Singer, S., Chie, W., . . . Greimel, E. (2012). Quality of life characteristics inpatients with cervical cancer. European journal of cancer, 48(16), 3009-3018.

Bruni, L., Barrionuevo-Rosas, L., Albero, G., Serrano, B., Mena, M., Gómez, D., . . . de Sanjosé, S. (2018). ICO/IARC Information Centre on HPV and Cancer (HPV Information Centre). human papillomavirus and related diseases in the world. Summary report 27 July 2017. 
Jurnal Aisyah: Jurnal Ilmu Kesehatan, 5(2), December 2020, - 189 Tetti Solehati; Bhekti Imansari; Devita Madiu; Cecep Eli Kosasih; Yanti Hermayanti; Henny Suzana Mediani

Cholli, P., Bradford, L., Manga, S., Nulah, K., Kiyang, E., Manjuh, F. ... Liu, Y. (2018). Screening for cervical cancer among HIVpositive and HIV-negative women in Cameroon using simultaneous co-testing with careHPV DNA testing and visual inspection enhanced by digital cervicography: findings of initial screening and one-year follow-up. Gynecologic oncology, 148(1), 118-125.

Cohen, P. A., Jhingran, A., Oaknin, A., \& Denny, L. (2019). Seminar Cervical cancer.

Dunleavey, R. (2008). Cervical cancer: a guide for nurses: John Wiley \& Sons.

Ersin, F., \& Bahar, Z. (2017). Effects of nursing interventions planned with the health promotion models on the breast and cervical cancer early detection behaviors of the women. International Journal, 10(1), 421.

Ferlay, J., Soerjomataram, I., Dikshit, R., Eser, S., Mathers, C., Rebelo, M., . . . Bray, F. (2015). Cancer incidence and mortality worldwide: sources, methods and major patterns in GLOBOCAN 2012. International journal of cancer, 136(5), E359-E386.

Han, H.-R., Song, Y., Kim, M., Hedlin, H. K., Kim, K., Ben Lee, H., \& Roter, D. (2017). Breast and cervical cancer screening literacy among Korean American women: A community health worker-led intervention. American journal of public health, 107(1), 159-165.

Harlianty, R., \& Paramastri, I. (2020). The role of religious coping as a moderator of the relationship between psychological burden and quality of life among caregiver of women with breast cancer. Journal of Psychological Perspective, 2(2), 71 78

Retrieved from https://ukinstitute.org/journals/iopp/article/view/220 6

Higgins, J. P., \& Green, S. (2011). Cochrane handbook for systematic reviews of interventions (Vol. 4): John Wiley \& Sons.

Isaka, Y., Inada, H., Hiranuma, Y., \& Ichikawa, M. (2017). Psychological impact of positive cervical cancer screening results among Japanese women. Int J Clin Oncol, 22(1), 102106.

Kemenkes, K. K. (2019). Data dan Informasi Profil Kesehatan Indonesia 2018. Retrieved from Retrieved from http://www.depkes.go.id/ website:

Kitchener, H., Gittins, M., Cruickshank, M., Moseley, C., Fletcher, S., Albrow, R., . . C Crosbie, E. (2018). A cluster randomized trial of strategies to increase uptake amongst young women invited for their first cervical screen: The STRATEGIC trial. Journal of medical screening, 25(2), 88-98.

Kolutek, R., Avci, I. A., \& Sevig, U. (2018). Effect of planned follow-up on married women's health beliefs and behaviors concerning breast and cervical cancer screenings. Journal of Cancer Education, 33(2), 375-382.

Kwok, C., \& Lim, D. (2016). Evaluation of a culturally tailored education to promote breast and cervical cancer screening among Chinese-Australian women. Journal of Cancer Education, 31(3), 595-601.

Li, J., Huang, J., Zhang, J., \& Li, Y. (2016). A home-based, nurse-led health program for postoperative patients with early-stage cervical cancer: A randomized controlled trial. European Journal of Oncology Nursing, 21, 174-180.

Lopez-Torres Hidalgo, J., Sanchez Ortiz, M. P., Rabanales Sotos, J., Simarro Herráez, M. J., Lopez-Torres Lopez, J., \& Campos Rosa, M. (2016). Effectiveness of three interventions in improving adherence to cervical cancer screening. European Journal of Cancer Prevention, 25(5), 423-429.
Moher, D., Liberati, A., Tetzlaff, J., \& Altman, D. G. (2009). Preferred reporting items for systematic reviews and metaanalyses: the PRISMA statement. Annals of internal medicine, 151(4), 264-269.

Murphy, J., Mark, H., Anderson, J., Farley, J., \& Allen, J. (2016). A RANDOMIZED TRIAL OF HPV SELF-SAMPLING AS AN INTERVENTION TO PROMOTE CERVICAL CANCER SCREENING AMONG WOMEN WITH HIV. Journal of lower genital tract disease, 20(2), 139.

Musa, J., Achenbach, C. J., O’Dwyer, L. C., Evans, C. T., McHugh, M., Hou, L., . . . Jordan, N. (2017). Effect of cervical cancer education and provider recommendation for screening on screening rates: A systematic review and meta-analysis. PloS one, 12(9), e0183924.

Odunyemi, F. T., Ndikom, C. M., \& Oluwatosin, O. A. (2018). Effect of Nursing Intervention on Mothers' Knowledge of Cervical Cancer and Acceptance of Human Papillomavirus Vaccination for their Adolescent Daughters in AbujaNigeria. Asia-Pacific journal of oncology nursing, 5(2), 223.

Pfaendler, K. S., Wenzel, L., Mechanic, M. B., \& Penner, K. R. (2015). Cervical cancer survivorship: long-term quality of life and social support. Clinical therapeutics, 37(1), 39-48.

Sharma, D., Rohilla, L., Bagga, R., Srinivasan, R., Jindal, H. A., Sharma, N., . . . Singh, R. K. (2018). Feasibility of implementing cervical cancer screening program using smartphone imaging as a training aid for nurses in rural India. Public Health Nursing, 35(6), 526-533.

Smeltzer, S., \& Bare, B. G. (2009). Textbook of medical surgical nursing, 9th: Philadelphia, Lippincot.

Thapa, N., Maharjan, M., Xiong, Y., Jiang, D., Nguyen, T.-P., Petrini, M. A., \& Cai, H. (2018). Impact of cervical cancer on quality of life of women in Hubei, China. Scientific reports, 8(1), 11993.

Weston, C., Page, R., Jones-Schubart, K., \& Akinlotan, M. (2018). Improving Cancer Screening for Underserved Women Through an FNP Student-Led Clinic. The Journal for Nurse Practitioners, 14(5), e101-e104.

WHO, W. H. O. (2014). Comprehensive Cervical Cancer Control. (Vol. 2).

Zhang, H., Li, Y., Li, M., \& Chen, X. (2019). A randomized controlled trial of mindfulness-based stress reduction for insomnia secondary to cervical cancer: Sleep effects. Applied Nursing Research. 